\title{
Growth, Photosynthesis and Quality of Water Spinach (Ipomoea aquatica) as Influenced by Magnetic Nanoparticles (MNP) Application
}

\author{
Rukhsar- E- Rashim Mohammed Yusufirashim ${ }^{1}$, Mohd Hafiz Ibrahim ${ }^{1^{*}}$, \\ Che Azurahanim Che Abdullah ${ }^{1}$ and Ayu Azera Izad ${ }^{1}$ \\ ${ }^{1}$ Department of Biology, Faculty of Science, Universiti Putra Malaysia, 43400 Serdang Selangor, \\ Malaysia.
}

Authors' contributions

This work was carried out in collaboration among all authors. Authors MHI and RERMY designed the study, performed the statistical analysis, wrote the protocol and wrote the first draft of the manuscript. Authors CACA and AAI managed the analyses of the study. Author AAI managed the literature searches. All authors read and approved the final manuscript.

Article Information

DOI: 10.9734/ARRB/2019/v31i630065

Editor(s):

(1) Dr. Ahmed Medhat Mohamed Al-Naggar, Professor, Plant Breeding, Agronomy Dept., Faculty of Agriculture, Cairo University, Egypt.

(2) Dr. George Perry, Dean and Professor of Biology, University of Texas at San Antonio, USA.

Reviewers:

(1) Toshik larley da Silva, Federal University of Viçosa, Brazil.

(2) Fernado F. Putti, Sao Paulo State University, Brazil.

(3) Joseph Onyango Gweyi, Kenyatta University- Kenya. Complete Peer review History: http://www.sdiarticle3.com/review-history/47894

Original Research Article

Received 18 January 2019

Accepted 01 April 2019

Published 10 May 2019

\section{ABSTRACT}

Aims: To characterize the growth, carbon assimilation and quality of Ipomoea aquatica as influenced by magnetic nanoparticles (MNP) application as well as to determine the best rates of iron oxide nanoparticles that give high growth, carbon assimilation and quality of Ipomoea aquatica. Study Design: Ipomoea aquatica plants were exposed to four different treatments of magnetic iron oxide nanoparticles $\left(\mathrm{Fe}_{3} \mathrm{O}_{4}\right)\left(0,50,100\right.$ and $\left.150 \mathrm{mg} \mathrm{L}^{-1}\right)$. The experiment was conducted in a randomized complete block design (RCBD) with 3 replications. One unit of experiment consisted of 8 plants and there were 96 plants used in the experiment.

Place and Duration of Study: Department of Biology, Faculty of Science, Universiti Putra Malaysia, between March 2018 and July 2018. 
Methodology: The growth parameters measured included: plant height, basal diameter, total leaf number, leaf temperature, total chlorophyll content and plant biomass. The carbon assimilation parameters were measured using IRGA (Infrared Gas Analyzer, LICOR 6400 XT Portable Photosynthesis System). i.e. transpiration rate $(E)$, stomatal conductance and water use efficiency (WUE). The chlorophyll fluorescence were measured by using Pocket PEA that measured maximum efficiency of photosystem ii, (fv/fm), maximum quantum yield of phytochemical and nonphotochemical process in photosystem II (fv/fo), minimal fluorescence (fo), performance index (PI) and Density of Reaction Centers Per PSII Antenna Chlorophyll (RC/ABS). Total phenolics and flavonoids contents in leaves were measured using Folin-Ciocalteu method.

Results: It was observed that plant height, shoot length, plant temperature, total biomass, and total chlorophyll content were significantly influenced $(p \leq 0.05)$ by the different concentrations of magnetic nanoparticles. The net photosynthetic rate $(A)$, transpiration rate $(E)$, stomatal conductance (gs), maximum efficiency of photosystem II (Fv/fm), maximum quantum yield of phytochemical and nonphotochemical process in photosystem II (Fv/fo), performance index and the density of reaction centers per PSII antenna chlorophyll of Ipomoea aquatica were significantly reduced at higher concentration of magnetic nanoparticles. However, water use efficiency and minimal fluorescence value (Fo) of Ipomoea aquatica increased with increase of MNP concentration. In addition, the application of magnetic nanoparticles significantly influenced $(P \leq 0.05)$ the total flavonoids and total phenolics content in water spinach. Both of these parameters were increased when higher concentration of magnetic nanoparticles was applied to Ipomoea aquatica. This study showed that MNP affected the growth, carbon assimilation and secondary metabolites production of Ipomoea aquatica.

Conclusion: In conclusion, the higher concentration of magnetic nanoparticles reduced the growth rate and carbon assimilation of water spinach and enhanced the production of secondary metabolites.

Keywords: Vegetables; nanoparticles; growth; photosynthesis; biometabolites.

\section{INTRODUCTION}

Based on the data from Department of Statistics Malaysia, agriculture sector was operated at 11,628 establishments in the year 2015 with an annual growth of 5.7 percent [1] and vegetables were contributing to agricultural commodities in which spinach (Spinicia oleracia), long bean (Vigna unguiculata), mustard (Brasica oleracia), eggplant (Solanum melongena), tomato (Solanum lycopersicum) and cucumber (Cucumis sativus) were selected by which more than 100 percent were recorded in self-sufficiency ratio [2]. Malaysia population in 2018 is estimated at 32.4 million compared to 32.0 million in 2017 by which 1.1 per cent as the growth rate [3]. As the population increases, the demand for food and commercial energy is accelerating to fulfill the population requirements. According to Department of Agriculture Malaysia, water spinach (Ipomoea aquatica) is one of the vegetables suggested by Malaysia government to be consumed widely due to its low price and Asia had consumed water spinach at the highest rate compared to other vegetables [4].

Ipomoea aquatic, also known as water spinach, is a popular vegetable in countries like Malaysia,
Hong Kong, Taiwan and other Asia countries. This edible vegetable is classified into the family Convolvulaceae. Water spinach is an aquatic or semi-aquatic yearly herb which usually creeps on moist soil or sand besides floating in water [5]. Countries like Southern Asia, Bangladesh, China and India had been using Ipomoea aquatica in folk medicine against different diseases including diabetes, malfunction of liver, constipation and Arsenic poisoning as it is known for its high nutritive values and consumable leafy vegetables [5]. Water spinach is also rich in minerals like flavonoids, phenolics and carotenes. As water spinach is easily grown plant, has short time to harvest period and well adapted to environment changes, this makes the plant favorable for cultivation. However, water spinach could accumulate foreign minerals like Cadmium, Zinc and Copper which enables it to be used as the sample plant for research [6].

Metals such as nickel, cobalt, and iron are used to demonstrate magnetic properties in which their magnetic particle size are within nanoscale [7]. Currently, magnetic nanoparticles have attracted researchers from different background like biotechnology, biomedicine and agriculture because this material possess wide applications 
and easy to be produced However, the application of magnetic nanoparticles relies on the particle's condition on its steadiness [8]. The application of magnetic nanoparticles in the study of plant currently have attracted interests of researchers for its ability to permit a particular localization to discharge their load as conveyed to the plants. Recent studies being applied on pumpkin plants to test on the specific localization, take-up, and translocation of magnetic nanoparticles (under $50 \mathrm{~nm}$ ) [9]. Besides, gas exchange is also being influenced by the use of magnetic nanoparticles in which they act on photosynthetic surface causing foliar warming and changes physiological process and cell elements of plants as the leaves are faced with stomatal obstacle [10].

The application of magnetic nanoparticles may enhance or retard the growth of I. aquatica through: carbon nanotubes that increased the leaf gas trades properties of the plant. It was seen in Arabidopsis thaliana that treatment with single wall carbon nanotubes (SWCNT) led to higher plant photosynthetic, photoabsorption and higher electron transport rates contrasted with the plant that was not treated with the materials. This was expected due to a higher productivity of chloroplast when cooperated with the nanomaterials [11].

Secondary metabolites are also important factors that are influenced by the magnetic nanoparticle application. Secondary metabolites are the natural products present in low amounts and whose production rely on different species, genera and families. Secondary metabolites are important in protecting plants from insects and pathogens, besides shaping imperative UVradiation absorbing compounds that eventually reduce the chances for the plant to die [12]. The production of flavonoids and phenolics are the determinants for the production of secondary metabolite in plant. It is often observed that plants undergoing stress have higher total flavonoid and phenolics contents due to defensive mechanism in them. The signal in plant to produce secondary metabolites is usually stimulated by the accumulation of heavy metals like zinc, iron, and nickel which generates Reactive Oxygen Species (ROS) and induces oxidative stress in plant. Consequently, the induction of oxidative stress causes changes in signal transduction for the mechanism of gene coding and enzyme [13]. Besides, the production of ROS may cause damages to cell membrane, cell structure and photosynthetic site and thus the production of flavonoid at the generation site act as defensive mechanism due to its high antioxidant properties. In addition, induced phenolics are produced when the plant faces physical injury, infection or environmental stresses due to heavy metal irradiation or temperature [14].

The low toxicity level of magnetic nanoparticles such as super paramagnetic nanoparticles (SPION) has been the reason for growing studies on the application of magnetic nanoparticles on organisms. A study shows that iron oxide nanoparticles is safe and non-cytotoxic at the level of $100 \mu \mathrm{g} \mathrm{mL}^{-1}$ when being compared with few metal oxide nanoparticles in vitro [15]. In one of the studies related to iron oxide nanoparticles exposure on sunflower plant, Helianthus annus, it was seen that at the concentration of $50-100 \mathrm{mg}$ $\mathrm{L}^{-1}$ the exposure resulted in reduction of root water pressure of the plant [16]. Besides, a study by Liu, Zhang and Lal [17] showed that the iron oxide nanoparticles were less toxic, besides stimulating root elongation during the germination of lettuce, Lactuca sativa at the concentration of $5-20 \mathrm{mg} \mathrm{L}^{-1}$ while inhibited root elongation at $50 \mathrm{mg} \mathrm{L}^{-1}$ [18].

Magnetic nanoparticles application is currently recognized in biomedicine to treat various diseases but is still far behind in plant biology. Magnetic-based materials can be used in production of certain chemicals to protect plant systematically from diseases besides controlling externally the movement of nanocarriers in the plant by using high power external magnet [19]. As water spinach is well known for its importance in culinary as vegetable and in traditional medicine, this study would help the plant to be continuously used in studies.

The study of $l$. aquatica in the aspects of biochemical and physical towards magnetic nanoparticles is still far behind in current research. Besides, the research on the impacts of magnetic nanoparticles on growth, carbon assimilation and quality of plant in form of secondary metabolites production is still few in science studies. Hence, this research was conducted with few objectives which are to relate the growth, carbon assimilation and quality of $I$. aquatica as influenced by magnetic nanoparticles application, to determine the best concentration of magnetic nanoparticles that can promote the optimum growth and quality of $I$. aquatica and to infer the relationship between growth and secondary metabolites of $I$. aquatica as affected by magnetic nanoparticles application. 


\section{MATERIALS AND METHODS}

\subsection{Synthesis of Iron Oxide Nanoparticles $\left(\mathrm{Fe}_{3} \mathrm{O}_{4}\right)$}

The iron oxide nanoparticles $\left(\mathrm{Fe}_{3} \mathrm{O}_{4}\right)$ were synthesized using co-precipitation method [20]. Iron (III) chloride powder and Iron (II) chloride powder were mixed in the ratio of $2: 1$ in a 250 $\mathrm{mL}$ conical flask and were dissolved in $150 \mathrm{ml}$ of deionized water. The solution was heated at $45^{\circ} \mathrm{C}$ bubbled with nitrogen gas for 15 minutes. The solution was then added with $20 \mathrm{~mL}$ of $25-$ $30 \%$ ammonia solution and stirred at 800 rpm for an hour. Then, the Iron (III) oxide nanoparticles produced was collected by magnetic decantation. The $\mathrm{Fe}_{3} \mathrm{O}_{4}$ product was then washed three times with acetone and centrifuged. The product was left to dry in furnace one night and grinded after drying process to obtain the powder form. $\mathrm{Fe}_{3} \mathrm{O}_{4}$ produced were in black colored fine powder.

\subsection{Plant Materials and Maintenance}

The experiment was conducted at the Vegetables Field plot for Teaching and Research, Taman Pertanian Universiti, Universiti Putra Malaysia. The source of planting materials in the study was the seeds of I. aquatica. Seeds of $I$. aquatica were propagated for 14 days in a tray and transplant to polybags containing a mixture of top soil and sand (ratio 3:1). After 1 month, I. aquatica plants were exposed to four different treatments of $\mathrm{Fe}_{3} \mathrm{O}_{4}(0,50,100$ and 150 $\left.\mathrm{mg} \mathrm{L}^{-1}\right)$. The magnetic nanoparticles were conveyed to the plants through watering. The magnetic nanoparticles were diluted in distilled water before being applied to the plants. Each plant was watered with $40 \mathrm{~mL}$ of magnetic nanoparticle solution. To maintain the plant growth and avoid plant wilting or attack by any major plant disease that affect plants, maintenance was done time to time.

\subsection{Experimental Design}

The polybags were arranged accordingly to Completely Randomized Block Design (RCBD) with replication of 3 blocks. One unit of experiment consisted of 8 plants, and there were total of 96 plants utilized in the experiment.

\subsection{Data Collection}

Data collection of plant growth were done on Week 3, 6, 9 and 12 while the destructive analysis and leaf gas exchange measurement were conducted on the $12^{\text {th }}$ week.

\subsubsection{Plant growth measurement}

The plant growth measurement was done to obtain the water spinach plant height, number of leaf, diameter of stem, root to shoot ratio, plant temperature and the chlorophyll content.

\subsubsection{Plant height}

Measuring tape was used to measure the plant height which starting from stem at soil surface up to the highest shoot growth or at its tip.

\subsubsection{Plant basal diameter}

The basal tips of the plant were measured by using vernier caliper.

\subsubsection{Plant leaves number}

The whole leaves of the plants were counted manually (one by one piece) and then recorded in every 3 weeks.

\subsubsection{Plant leaf temperature determination}

Infrared (IR) Thermometer was used to measure plant leaf temperature.

\subsubsection{Chlorophyll content measurement}

Total chlorophyll content in the leaves was measured using SPAD 502 chlorophyll meter (Spectrum Tech Inc; Aurora, IL; USA). The leaf was clipped under the chlorophyll meter clipper to obtain the reading for every treatment in each of the replication. The data was collected every week from week zero until week 12 of the experiment.

\subsubsection{Plant fresh weight measurement}

The plants were removed from the soil carefully and the dirt from the soil was rinsed with tap water. The shoot, root and the leaf parts were separated and weighed using analytical balance.

\subsubsection{Plant biomass (Dry weight) measurement}

All the plants were dried for 2 days in the oven at $60^{\circ} \mathrm{C}$. The dry weight of root, stem and leaf per seedling were recorded as plant biomass. 


\subsubsection{Root to shoot ratio}

The root to shoot ratio was determined by dividing the dry weight of the root with the dry weight of the shoot.

\subsubsection{Leaf gas exchange measurement}

A LI-6400XT (Li-COR Inc; Nebraska; USA) portable photosynthesis system gave the reading of leaf gas exchange. The instrument was warmed and calibrated for 30 minutes with the ZERO IRGA mode. The measurements used optimal conditions set at $400 \mu \mathrm{mol} \mathrm{mol}{ }^{-1} \mathrm{CO}_{2}$, $30^{\circ} \mathrm{C}$ cuvette temperature, $60 \%$ relative humidity with air flow rate set at $500 \mathrm{~cm} 3 \mathrm{~min}^{-1}$ and modified cuvette condition of $800 \mu \mathrm{molm}^{-2} \mathrm{~s}^{-1}$ photosynthetically photon flux density (PPFD). The fully expanded young leaves were used to measure net photosynthesis $(A)$, transpiration rate $(E)$ and stomata conductance $\left(g_{s}\right)$ which also gave the measurement of gas exchange. It was an automatic operation therefore the data was recorded in the LI-6400XT console and further analyzed by Photosyn Assistant Software (Dundee Scientific, Dundee, UK). Precautions step were considered while taking the measurements to avoid errors.

\subsubsection{Chlorophyll fluorescence determination}

Measurements of chlorophyll fluorescence were taken from fully expanded second leaves. Leaves were darkened for 15 min by attaching light-exclusion clips to the central region of the leaf surface. Chlorophyll fluorescence was measured using a portable chlorophyll fluorescence meter (Pocket PEA, Hansatech Instruments Ltd., Norwich, UK). Measurements were taken at $>3,000 \mu \mathrm{mol} \mathrm{m} \mathrm{s}^{-1}$ and recorded for up to 5 seconds. The fluorescence responses were induced by emitting diodes. Measurement of $f_{O}$ (initial fluorescence), $f_{m}$ (maximum fluorescence) and $f_{v}$ (variable fluorescence) were obtained from this procedure. $f_{V}$ is derived as the difference between $f_{m}$ and $f_{0}$. Fluorescence values recorded, include the initial/minimal fluorescence $\left(f_{0}\right)$, the ratio of variable to maximum fluorescence $\left(\mathrm{f}_{\mathrm{v}} / \mathrm{f}_{\mathrm{m}}\right)$ which represents the maximum quantum yield of photosystem II (PS II), and the ratio of variable to minimum fluorescence $\left(\mathrm{f}_{\mathrm{v}} / \mathrm{f}_{\mathrm{O}}\right)$ which estimates the maximum primary yield of photochemistry of PS II. The $f_{m}$ is the maximal fluorescence value, and $f_{V}$ is the variable fluorescence calculated as $f_{m}-$ fo .

\subsubsection{Total phenolics and flavonoids quantification}

The total phenolics and flavonoid measurement follow methods from Ibrahim et al [21]. Plant tissue samples $(0.1 \mathrm{~g})$ that was initially ground were extracted with $80 \%$ ethanol $(10 \mathrm{~mL})$ on an orbital shaker at $50^{\circ} \mathrm{C}$ for 120 minutes. The mixture was filtered, and the filtrate used for the quantification of total flavanoids and total phenolics. Total phenolics content of the leaf samples was determined by using FollinCiocalteu reagent (Sigma Aldrich, Missouri, USA; diluted 10-fold). The absorbance measured at $725 \mathrm{~nm}$. The results were expressed as $\mathrm{mg} \mathrm{g}^{-1}$ gallic acid equivalent ( $m g$ GAE $\mathrm{g}^{-1}$ dry sample). For total flavonoids determination, a sample (1 $\mathrm{mL}$ ) mixed with $\mathrm{NaNO}_{3}$ (Sigma Aldrich, Missouri, USA; $0.3 \mathrm{~mL}$ ) in a test tube which covered with aluminum foil, and left for $5 \mathrm{~min}$. Then $10 \% \mathrm{AlCl}_{3}$ (Wako Pure Chemical Industries Ltd; Tokyo, Japan; $0.3 \mathrm{~mL}$ ) added followed by addition of $1 \mathrm{M}$ $\mathrm{NaOH}$ (Kanto Chemical Co. Inc.; Hokkaido, Japan; $2 \mathrm{~mL}$ ). Later, the absorbance was measured at $510 \mathrm{~nm}$ using a spectrophotometer with rutin as a standard (results expressed as $\mathrm{mg}$ $\mathrm{g}^{-1}$ rutin dry sample).

\subsection{Statistical Analysis}

The recorded data was analyzed by using statistic software known as Statistical Package for Social Sciences (SPSS) with the version 24. A two-way ANOVA test was carried out for data analysis for all the parameters in the experiment. Data was significant if the $p$-value level $\leq 0.05$.

\section{RESULTS AND DISCUSSION}

\subsection{Plant Height}

Fig. 1 showed that, different concentrations of magnetic nanoparticles application influenced significantly the plant height of $I$. aquatica at $P \leq$ 0.05 in week 3 . The highest plant height was observed in $0 \mathrm{mg} \mathrm{L}^{-1}(14.10 \mathrm{~cm})$, followed by 50 $\mathrm{mg} \mathrm{L}^{-1}(12.2 \mathrm{~cm}), 10 \mathrm{mg} \mathrm{L}^{-1}(11.2 \mathrm{~cm})$ and lowest in $150 \mathrm{mg} \mathrm{L}^{-1}(11.1 \mathrm{~cm})$, these differences were significantly different. The current result indicates that the application of magnetic nanoparticles at higher concentration reduced the plant height of I. aquatica. Research had shown that higher concentration of $\mathrm{Fe}_{3} \mathrm{O}_{4}$ with pro-longed exposure may lead to iron toxicity in the plant. The plants that faced toxicity during growth stage may initiate stress and causes reduction in plant 
height due to effects of iron toxicity like production of free radicals, root break down and bronzing of leaves which lead to yield loss [22]. The application of $\mathrm{Fe}_{3} \mathrm{O}_{4}$ stimulate the production of Reactive Oxygen Species (ROS) under the condition of excess or deficiency of $\mathrm{Fe}_{3} \mathrm{O}_{4}$ that responsible of signaling molecule that stimulate or inhibit plant growth $[23,24]$.

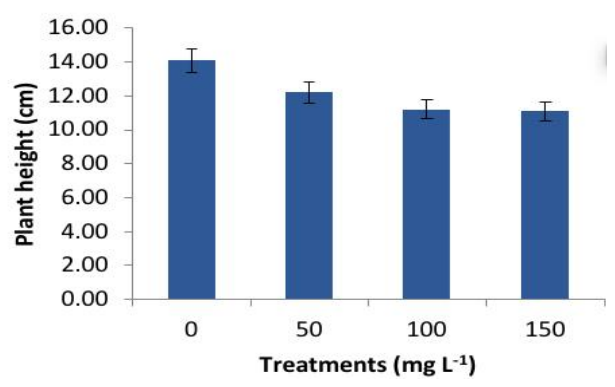

Fig. 1. The impact of magnetic nanoparticles on plant height of Ipomoea aquatic

Data are mean \pm standard error of mean (SEM). $N=24$

\subsection{Basal Diameter}

Different concentration of magnetic nanoparticles application has significantly influenced the basal diameter of $I$. aquatica ( $P \leq 0.05$; Fig. 2$)$ in week 12. At $12^{\text {th }}$ week, the application of magnetic nanoparticles showed significant increase in basal diameter of $l$. aquatica at higher concentration which is at $150 \mathrm{mg} \mathrm{L}^{-1}$. The smallest basal diameter was observed in $0 \mathrm{mg} \mathrm{L}^{-}$ $1(0.51 \mathrm{~cm})$, followed by $100 \mathrm{mg} \mathrm{L}^{-1}(0.56 \mathrm{~cm}), 50$ $\mathrm{mg} \mathrm{L}^{-1}(0.571 \mathrm{~cm})$ and greatest in $150 \mathrm{mg} \mathrm{L}^{-1}$ $(0.74 \mathrm{~cm})$. The current result indicates that the application of magnetic would promote the stem diameter of $I$. aquatica. Based on research, aquaporins are found on tonoplast or also known as vacuolar membrane which allows water to be freely moves across the cells in the symplastic route. Therefore, the abundance of aquaporins found on the membrane depends on the regulation of water flow. During water stress due to high concentration of nanoparticles may lead to induction of turgor-responsive aquaporins to maintain turgor pressure. This would cause the vacuole size to increase that brings to cell expansion and increased of stem diameter [25]. Besides, a research done on radish cotyledon shows that increase in turgor pressure increase the cell expansion and growth. However, the study claimed that under unfavorable condition, cell would not divide [26]. Therefore, it is proposed that higher concentration of $\mathrm{Fe}_{3} \mathrm{O}_{4}$ caused increase in stem diameter.

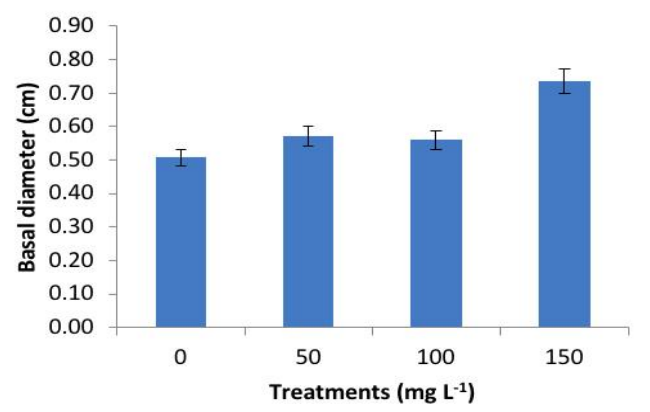

Fig. 2. The impact of magnetic nanoparticles on basal diameter of Ipomoea aquatic

Data are mean \pm standard error of mean (SEM). $N=24$

\subsection{Total Biomass}

Based on Fig. 3, different concentration of magnetic nanoparticles significantly influenced the total biomass of $I$. aquatica $(p \leq 0.05)$ in week 12. In week 12 , a significant effect was observed by which the application of $\mathrm{Fe}_{3} \mathrm{O}_{4}$ with the concentration of $150 \mathrm{mg} \mathrm{L}^{-1}$ increased the biomass of water spinach. The highest total biomass was observed in $150 \mathrm{mg} \mathrm{L}^{-1}$ (4.21 gram), followed by $50 \mathrm{mg} \mathrm{L}^{-1}$ (2.22 gram), 100 $\mathrm{mg} \mathrm{L}^{-1}$ (2.02 gram), and $0 \mathrm{mg} \mathrm{L}^{-1}$ (1.98 gram). The result obtained showed that iron oxide nanoparticles with highest concentration would increase the total biomass of $I$. aquatica. This result was in agreement with the finding by Sheykhbaglou and Sedghi [27]. From their research, it was found that the use of iron oxide nanoparticles increased the dry weight of pod and peanut plant. They found that the application of $\mathrm{Fe}_{3} \mathrm{O}_{4}$ helped in transferring iron and photosynthate particle in the leaves of plants. Besides, the total biomass of Vigna radiata applied with $\mathrm{Fe}_{3} \mathrm{O}_{4}$ showed a positive result compared to the application of ferum ions. This was $\mathrm{d}$ due to the increase of a-amylase activity in the seeds exposed to $\mathrm{Fe}_{3} \mathrm{O}_{4}$. The increase of total biomass was also observed in Spinacea oleracea applied with magnetic nanoparticles [18]. However, study by Jeyasubramanian et al. [28] showed that higher concentration of $\mathrm{Fe}_{3} \mathrm{O}_{4}$ (200 $\mathrm{mg} \mathrm{L}^{-1}$ ) cause decrease in both wet and dry weight of spinach [29].

\subsection{Leaf Temperature}

Fig. 4 showed that magnetic nanoparticle significantly influenced the plant temperature of $I$. aquatica $(P \leq 0.05)$ in week 12 . The highest plant temperature was observed at $100 \mathrm{mg} \mathrm{L}^{-1}$, $\left(32.0^{\circ} \mathrm{C}\right)$ followed by $150 \mathrm{mg} \mathrm{L}^{-1}\left(31.1^{\circ} \mathrm{C}\right), 150$ 
$\mathrm{mg} \mathrm{L}^{-1}\left(30.8^{\circ} \mathrm{C}\right)$ and $0 \mathrm{mg} \mathrm{L}^{-1}\left(28.7^{\circ} \mathrm{C}\right)$ in week 12. The result shows that a higher concentration of magnetic nanoparticles shows higher leaf temperature of water spinach. Plant temperature is often related to transpiration process. Transpiration is a cooling process taken by the plant to release water vapor from the plant through stomata and cuticle. Through transpiration, thermal energy is balanced by the loss of heat to its surrounding. Therefore, when the transpiration rate is decreased due to the accumulation of nanoparticles at the root surface and inhibits the water intake capacity, the plant temperature would increase. Besides, the stomata conductance also plays a major role in maintaining the leaf plant temperature. The closing and opening of stomata do give impact on the plant temperature [30]. Thus, higher concentration of $\mathrm{Fe}_{3} \mathrm{O}_{4}$ result higher plant temperature due to its relationship with transpiration rate and stomata conductance.

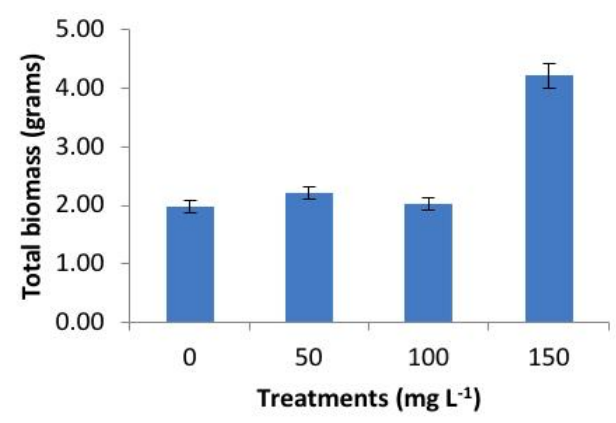

Fig. 3. The impact of magnetic nanoparticles on total biomass of Ipomoea aquatic

Data are mean \pm standard error of mean (SEM). $N=24$

\subsection{Total Chlorophyll Content}

Fig. 5 shows the impact of magnetic nanoparticle on total chlorophyll content of water spinach. There was significant effect of the application of magnetic nanoparticles on the water spinach chlorophyll content at $P \leq 0.05$. After 12 weeks of treatment, the highest chlorophyll content was observed in $I$. aquatica treated with $50 \mathrm{mg} / \mathrm{L}$ $\mathrm{Fe}_{3} \mathrm{O}_{4}$ (34), followed by $0 \mathrm{mg} \mathrm{L}^{-1}(22)$ and $100 \mathrm{mg}$ $\mathrm{L}^{-1}(20)$ and lowest in $150 \mathrm{mg} \mathrm{L}^{-1}(17)$. This result indicates that higher concentration of magnetic nanoparticles leads to decrease of chlorophyll content in water spinach which was supported by several studies. Based on research by Racuciu et al. [31], Zea mays plant treated with 20, 40, 60,80 , and $100 \mu \mathrm{I}^{-1}$ of $\mathrm{Fe}_{3} \mathrm{O}_{4}$ suspension concentration showed decreased in chlorophyll content. The magnetic nanoparticles showed both chemical and magnetic influence on the water spinach enzymatic structure that eventually influence the photosynthetic system of the plant at higher concentration. Besides, the application of nanoparticles would induce oxidative stress in plant that reduced the chlorophyll content in plant leaf. For example, zinc oxide nanoparticles had proven to reduce the chlorophyll content in wheat plant due to the formation of free radical [32]. Another research done on watermelon showed that the application of magnetic nanoparticles at higher concentration loss the content of chlorophyll. Due to the toxic substance exposure to the plant, the Malondialdehyde (MDA) production could be observed as a result of lipid peroxidation. Low level of MDA is important in protecting the structure and function of cell membranes. As the increase of MDA in plant with the presence of $\mathrm{Fe}_{3} \mathrm{O}_{4}$, the penetration of large particles into the cell is disturbed that result in less efficiency of cell. Thus, iron is claimed to be the cause for enzymatic activity inhibition that reduce chlorophyll synthesis [33].

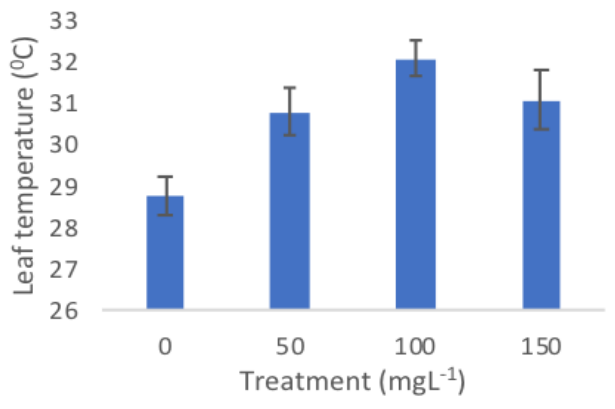

Fig. 4. The impact of magnetic nanoparticles on plant temperature of Ipomoea aquatic

Data are mean \pm standard error of mean (SEM). $N=24$

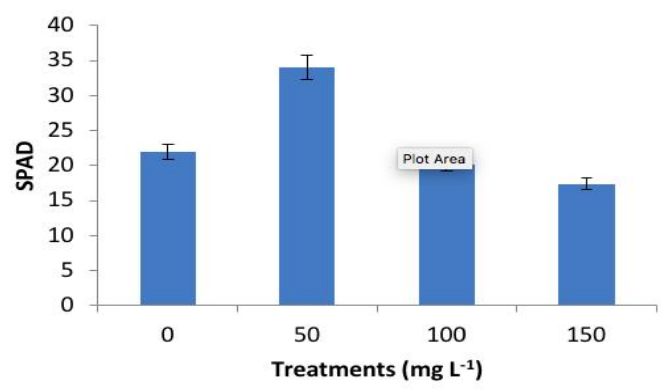

Fig. 5. The impact of magnetic nanoparticles on total chlorophyll content of Ipomoea aquatica

Data are mean \pm standard error of mean (SEM). $N=24$ 


\subsection{Net Photosynthesis Rate}

Fig. 6 showed the net photosynthesis rate $(A)$ of water spinach after 12 weeks of planting. The results shown that the net photosynthesis rate was significantly influenced $(p \leq 0.05)$ by the application of $\mathrm{Fe}_{3} \mathrm{O}_{4}$ during the planting period. The higher concentration of magnetic nanoparticles resulted in lower net photosynthesis rate of water spinach. The net photosynthesis of control treatment $\left(0 \mathrm{mg} \mathrm{L}^{-1}\right)$ was higher than other treatments: $50 \mathrm{mg} \mathrm{L}^{-1}, 100$ $\mathrm{mg} \mathrm{L}^{-1}$ and $150 \mathrm{mg} \mathrm{L}^{-1}$ that recorded $6.9 \mathrm{umol} \mathrm{m}-$ ${ }^{2} \mathrm{~s}^{-1}, 6.3 \mathrm{umol} \mathrm{m}-\mathrm{s}^{-1}, 3.4 \mathrm{umol} \mathrm{m}-\mathrm{s}^{-1}$, and 2.2 umolm- ${ }^{2} \mathrm{~s}^{-1}$ respectively. The photosynthesis rate could have been altered due to the application of magnetic nanoparticles by which these nanoparticles could block the pathway and caused stress to the water spinach. Although nanoparticles are in the size of nanometer but their entry into the plant may cause some changes either by enhancing or inhibiting the photosynthesis rate. In this case, the electron transport chain may be blocked by the nanoparticles and enhance stress to the plant manipulating and changing the normality of genes and enzymes like Rubisco. Rubisco is one of the enzymes that play an important role in the conversion of carbon dioxide into biological substances [34]. Therefore, the changes in production of Rubisco may lead to lower net photosynthesis rate with the application of magnetic nanoparticles.

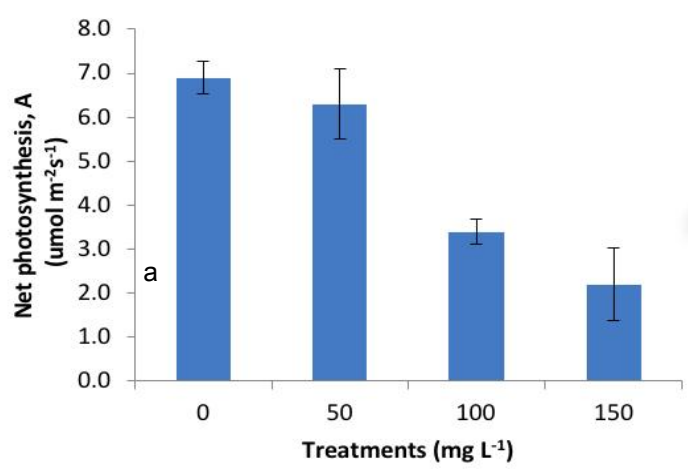

Fig. 6. The impact of magnetic nanoparticles on net photosynthesis rate of Ipomoea aquatic

Data are mean \pm standard error of mean (SEM). $N=24$

\subsection{Transpiration Rate}

Based on Fig. 7, the transpiration rate of $I$. aquatica was significantly influenced by the application of magnetic nanoparticles after 3 months of experimental period as $P \leq 0.05$. The transpiration rate was highest in $50 \mathrm{mg} \mathrm{L}^{-1}$ treatment followed by the control treatment, 100 $\mathrm{mg} \mathrm{L}^{-1}$ and $150 \mathrm{mg} \mathrm{L}^{-1}$ of $\mathrm{Fe}_{3} \mathrm{O}_{4}$ by $2.34 \mathrm{mmol}$ $\mathrm{H}_{2} \mathrm{O} \mathrm{m}^{-2} \mathrm{~s}^{-1}, 1.75 \mathrm{mmol} \mathrm{H}_{2} \mathrm{O} \mathrm{m}-\mathrm{s}^{-1}, 1.44 \mathrm{mmol}$ $\mathrm{H}_{2} \mathrm{O} \mathrm{m}-\mathrm{s}^{-1}$, and $0.80 \mathrm{mmol} \mathrm{H}_{2} \mathrm{O} \mathrm{m}^{2} \mathrm{~s}^{-1}$ respectively. This indicates that higher concentration of $\mathrm{Fe}_{3} \mathrm{O}_{4}$ would decrease the transpiration rate while an optimum concentration did not inhibit the transpiration rate in which in this case is $50 \mathrm{mg} \mathrm{L}^{-1}$ of iron oxide nanoparticles. Transpiration rate is linked up by photosynthesis rate by means if there is reduction in photosynthesis rate, the transpiration rate would decrease too. Besides, nanoparticles applied to the plant may cover the root surface of the plant and causes water stress in water spinach. This is supported by a research using Titanium oxide nanoparticle in maize in which the water transport capacity of the primary cell wall was reduced due to accumulation of nanoparticles at the plant leaf [35]. Besides, the research done on Citrullus lanatus to study the application of magnetic nanoparticles on the root activity showed that the $\mathrm{Fe}_{3} \mathrm{O}_{4}$ accumulated at the root surface that prevent the transmission of water and also other nutritional components by the plant [33].

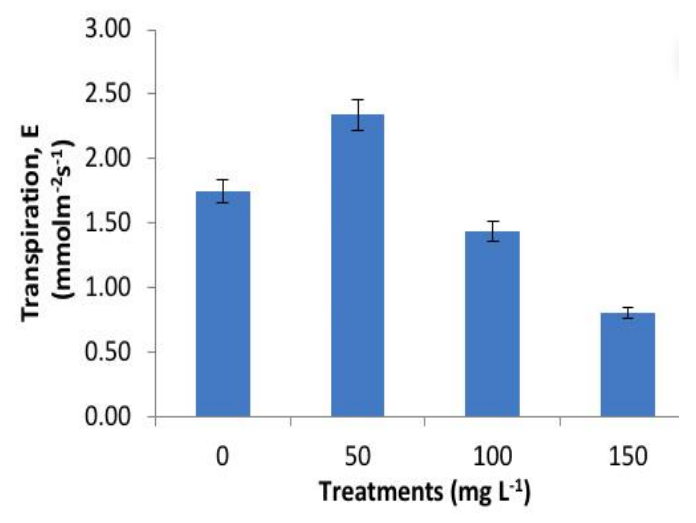

Fig. 7. The impact of magnetic nanoparticles on transpiration rate of Ipomoea aquatica Data are mean \pm standard error of mean (SEM). $N=24$

\subsection{Stomata Conductance}

The stomata conductance of water spinach was significantly affected by the application of magnetic nanoparticles as showed in Fig. 8 as $P \leq 0.05$. After 12 weeks of treatment application, the stomata conductance for $50 \mathrm{mg} \mathrm{L}^{-1} \mathrm{Fe}_{3} \mathrm{O}_{4}$ was the significantly highest compared to $0 \mathrm{mg} \mathrm{L}^{-}$ 
1 , $100 \mathrm{mg} \mathrm{L}^{-1}$ and $150 \mathrm{mg} \mathrm{L}^{-1}$ with $0.314 \mathrm{~mol} \mathrm{H}_{2} \mathrm{O}$ $\mathrm{m}^{-}{ }^{2} \mathrm{~s}^{-1}, 0.246 \mathrm{mmol} \mathrm{H} \mathrm{H}_{2} \mathrm{~m}^{-2} \mathrm{~s}^{-1}, 0.144 \mathrm{~mol} \mathrm{H}_{2} \mathrm{O}$ $\mathrm{m}^{-} \mathrm{s}^{-1}$, and $0.134 \mathrm{~mol} \mathrm{H} \mathrm{H}_{2} \mathrm{O} \mathrm{m}-{ }^{2} \mathrm{~s}^{-1}$ respectively. From the result, it was observed that higher concentration of $\mathrm{Fe}_{3} \mathrm{O}_{4}$ would decrease the stomata conductance of water spinach. Stomata conductance is determined by the degree of stomata aperture which estimates the rate of gas exchange and transpiration rate. A greater conductance is shown when the degree of stomata opening and its function in term of density and size is greater. When the plant undergoes greater photosynthesis and transpiration rate, the stomata conductance is greater. This statement is proven by the result of this experiment by which when the photosynthesis and transpiration rate of water spinach is lower for higher concentration of $\mathrm{Fe}_{3} \mathrm{O}_{4}$, the stomata conductance follows the same pattern. The application of magnetic nanoparticles may cause leakage of electrolyte in the plant which alters the mechanism of potassium pump that controls stomata opening. The accumulation of magnetic nanoparticles may cause the stomata to be closed or partially closed which directly reduce the stomata conductance [14].

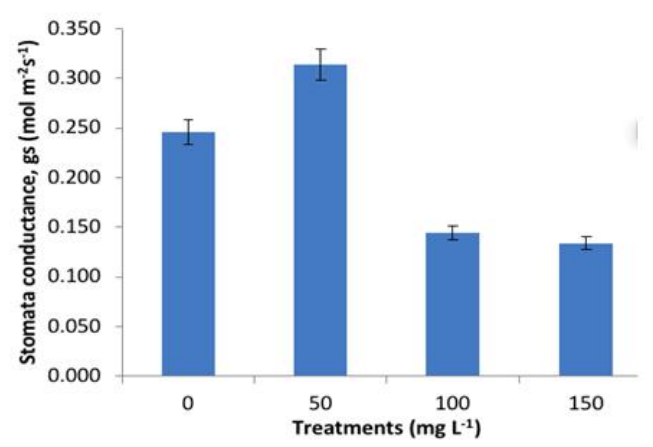

Fig. 8. The impact of magnetic nanoparticles on stomatal conductance of Ipomoea aquatic Data are mean \pm standard error of mean (SEM). $N=24$

\subsection{Water Use Efficiency}

From the Fig. 9, the result showed that the water use efficiency of water spinach was significantly affected by the application of $\mathrm{Fe}_{3} \mathrm{O}_{4}$ as $P \leq 0.05$ by which the highest water use efficiency was recorded for $150 \mathrm{mg} \mathrm{L}^{-1}$ treatment, followed by other treatments with $0 \mathrm{mg} \mathrm{L}^{-1}, 50 \mathrm{mg} \mathrm{L}^{-1}$ and $100 \mathrm{mg} \mathrm{L}^{-1}$ at $4.23,2.86,2.72$, and 2.44 umolCO $\mathrm{m}^{-2} \mathrm{~s}^{-1}$ respectively. From the result, it was observed that the water spinach with the highest concentration of $\mathrm{Fe}_{3} \mathrm{O}_{4}$ showed greater water use efficiency. Water use efficiency is one of the important determinants of plant growth under stress as the plant maximize the capturing of soil moisture when there is limitation of water supply or lower stomata conductance in order to increase yield production [36]. Water use efficiency is related with transpiration rate and defined as the ratio of moles $\mathrm{CO}_{2}$ assimilated per moles of water transpired [14]. Therefore, with the application of magnetic nanoparticles at higher concentration increase the transpiration rate of $I$. aquatica, the water use efficiency is also increased.

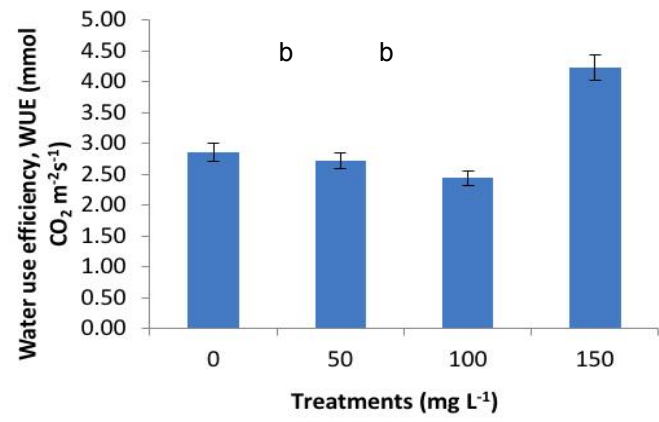

Fig. 9. The impact of magnetic nanoparticles on water use efficiency of Ipomoea aquatica Data are mean \pm standard error of mean (SEM). $N=24$

\subsection{Maximum Efficiency of Photosystem II}

Fig. 10 shows the effect of different concentration of $\mathrm{Fe}_{3} \mathrm{O}_{4}$ on maximum efficiency of photosystem II or known as $\mathrm{fv} / \mathrm{fm}$ ratio. The result of the application on water spinach was significant as $P \leq 0.05$ by which higher concentration of $\mathrm{Fe}_{3} \mathrm{O}_{4}$ showed lower $\mathrm{Fv} / \mathrm{Fm}$ value. The ratio of $\mathrm{fv} / \mathrm{fm}$ for $150 \mathrm{mg} \mathrm{L}^{-1}(0.65)$ was significantly lower than $100 \mathrm{mg} \mathrm{L}^{-1}(0.69)$ and followed by $50 \mathrm{mg} \mathrm{L}^{-1}$ (0.74) and $0 \mathrm{mg} \mathrm{L}^{-1}(0.76)$. The lowest Fv/Fm ratio showed by water spinach treated with 150 $\mathrm{mg} / \mathrm{l}$ clearly shows that higher concentration of $\mathrm{Fe}_{3} \mathrm{O}_{4}$ would reduce the efficiency of photosystem II. Fv/Fm is the main parameter used to detect any injury in photosystem II or photon inhibitory process as it is related to quantum yield of photosynthesis. The induction of stress on photosynthetic surface in plant would limit the transformation of light energy in photosystem II. Thus, the decrease in photosynthetic in plant would reduce the reduction of phytochemical activity in photosystem II [37]. 


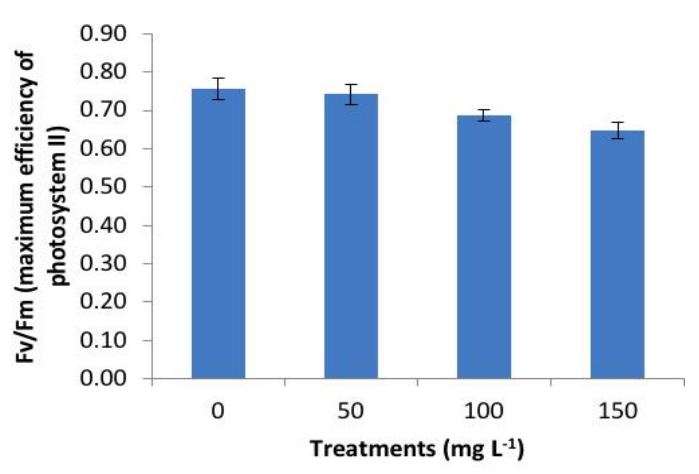

Fig. 10. The impact of magnetic nanoparticles on $\mathrm{fv} / \mathrm{fm}$ (maximum efficiency of photosystem II) of Ipomoea aquatica

Data are mean \pm standard error of mean (SEM). $N=24$

\subsection{Maximum Yield of Photosystem II}

Fig. 11 shows the effect of different concentration of $\mathrm{Fe}_{3} \mathrm{O}_{4}$ on maximum yield of photosystem II or known as $\mathrm{Fv} / \mathrm{Fo}$ ratio in 3 months planting periods. The result of the application on water spinach was significant as $P \leq 0.05$ by which higher concentration of iron oxide nanoparticles showed lower $\mathrm{Fv} / \mathrm{Fm}$ value. The ratio of fv/fm for $0 \mathrm{mg} \mathrm{L}^{-1}$ (3.15) and $50 \mathrm{mg} \mathrm{L}^{-1}$ (3.14) was significantly higher than $100 \mathrm{mg} \mathrm{L}^{-1}(2.40)$ and $150 \mathrm{mg} \mathrm{L}^{-1}$ (2.35). As the two parameters Fv/Fm ratio and Fv/Fo ratio showed the similar trend, it can be speculated that both parameters are related to each other. The Fv/Fo is more sensitive towards changes to efficiency of photosystem II compared to $\mathrm{Fv} / \mathrm{Fm}$ as it shows quantum yield of phytochemical and nonphotochemical process. This ratio indicates the state of photosystem II on the energy absorbed and damaged occurred due to plant stress in leaf. This ratio is also affected by the alteration of stomatal closure and carbon fixation process due to water and temperature stress [38]. Besides, the accumulation of magnetic nanoparticles in the photosystem I and II cause obstruction to photosynthesis in donor part of both photosystems that reduce the fv/fo ratio [37].

\subsection{Minimal Fluorescence}

Based on Fig. 12, the application of $\mathrm{Fe}_{3} \mathrm{O}_{4}$ had significantly influenced the minimal chlorophyll fluorescence yield of water spinach as $P \leq 0.05$. The Fo of water spinach treated with $100 \mathrm{mg} \mathrm{L}^{-1}$ and $150 \mathrm{mg} \mathrm{L}^{-1} \mathrm{Fe}_{3} \mathrm{O}_{4}$ were significantly higher compared to $0 \mathrm{mg} \mathrm{L}^{-1}$ and $50 \mathrm{mg} \mathrm{L}^{-1}, 722,726$, 653 and 607 respectively. From the result, it is shown that the Fo value increased as the concentration of $\mathrm{Fe}_{3} \mathrm{O}_{4}$ increased. The application of nanoparticles like titanium oxide showed that with the increase of its concentration, the minimal fluorescence value decreased as titanium oxide nanoparticles do protect the photosynthetic structure of the tomato plant under mild heat stress. However, the study by Gao et al. [39] showed that at high light intensity the minimal fluorescence in Ulmus elongata seedlings decreased. Therefore, the possible explanation for this would be the impact of magnetic nanoparticles on water spinach is complex and it depends both on the concentration of $\mathrm{Fe}_{3} \mathrm{O}_{4}$ and the environmental condition that would affect the activity of nanoparticles [40]. Besides, the application of magnetic nanoparticles increased the heat dissipation in water spinach as the absorbed light energy could not be used for photosynthesis [37].

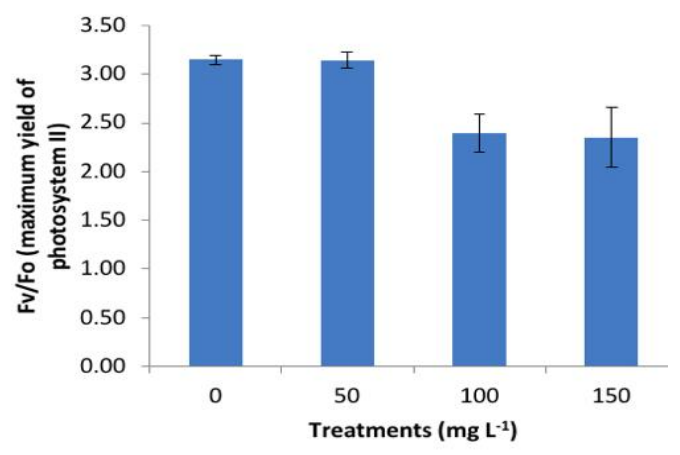

Fig. 11. The impact of magnetic nanoparticles on fv/fo (maximum yield of photosystem II) of Ipomoea aquatic

Data are mean \pm standard error of mean (SEM). $N=24$

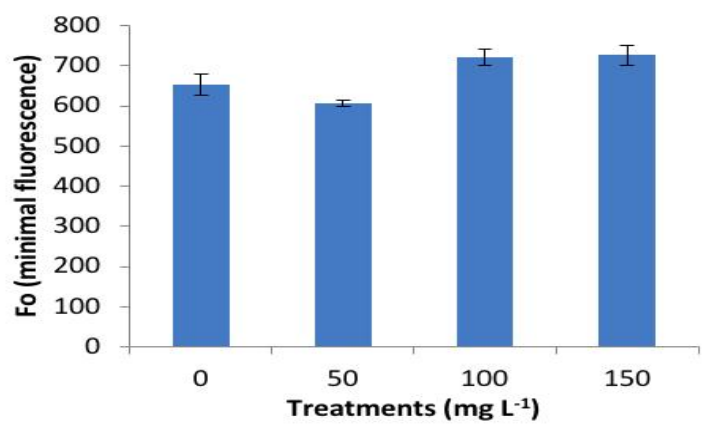

Fig. 12. The impact of magnetic nanoparticles on fo (minimal fluorescence) of Ipomoea aquatica

Data are mean \pm standard error of mean (SEM). $N=24$ 


\subsection{Performance Index}

From the Fig. 13, the result showed that the performance index of water spinach was significantly affected by the application of $\mathrm{Fe}_{3} \mathrm{O}_{4}$ as $P \leq 0.05$ by which the significantly highest performance index was recorded for $50 \mathrm{mg} / \mathrm{L}$ treatment, followed by other treatments with 0 $\mathrm{mg} \mathrm{L}^{-1}, 100 \mathrm{mg} \mathrm{L}^{-1}$ and $150 \mathrm{mg} \mathrm{L}^{-1}$ at 2.73, 2.51, 1.62 , and 1.48 respectively. From the result, it was observed that the water spinach with lower concentration of iron oxide nanoparticles showed greater performance index. Performance index is the one of the parameters which is sensitive to environmental conditions in a plant as it is used as a suitable tool to reflect water deficit in a plant system. Based on research, performance index had been used as a sensitive indicator of water stress in Triticum aestivum. Performance index is a combination formula that takes into account the measurement of RC/ABS, maximal energy reflux that reaches photosystem II and electron transport [41]. Therefore, the application of magnetic nanoparticles that changes the net photosynthetic rate and transpiration rate due to the accumulation of iron oxide nanoparticles at the root surface and the blockage of Electron Transport Chain had affected the performance index of water spinach. Besides, the carbon assimilation process and stomata conductance had correlated with the performance index of water spinach which concluded that higher concentration of $\mathrm{Fe}_{3} \mathrm{O}_{4}$ showed lower performance index in water spinach [42].

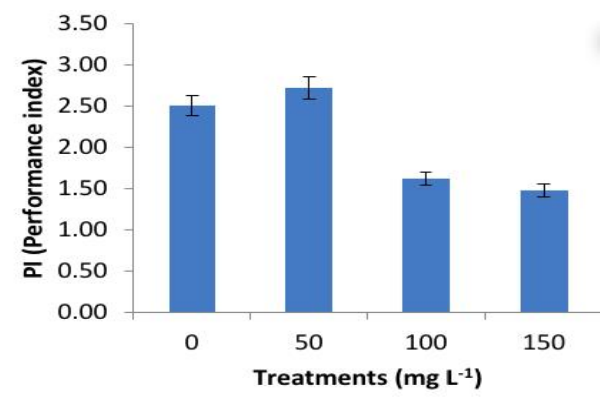

Fig. 13. The impact of magnetic nanoparticles on PI (performance index) of Ipomoea aquatic Data are mean \pm standard error of mean (SEM). $N=24$

\subsection{Density of Reaction Centers per PSII Antenna Chlorophyll}

Fig. 14 shows the effect of different concentration of $\mathrm{Fe}_{3} \mathrm{O}_{4}$ on density of reaction centers per
Photosystem II antenna chlorophyll in threemonth planting periods. The result of the application on water spinach was significant as $P \leq 0.05$ by which higher concentration of $\mathrm{Fe}_{3} \mathrm{O}_{4}$ showed lower density of reaction centers per Photosystem II antenna chlorophyll. The density of reaction centers per Photosystem II antenna chlorophyll for $0 \mathrm{mgL}^{-1}$ and $50 \mathrm{mgL}^{-1}$ is 0.71 which was significantly higher than $100 \mathrm{mg} \mathrm{L}^{-1}$ (0.56) and $150 \mathrm{mg} \mathrm{L}^{-1}$ (0.60). RC indicates the number of active reaction center in photosystem II while ABS shows the quantity of light absorbed by the antenna chlorophyll. Thus, RC/ABS indicate the total number of active radiation per light absorption [43]. Due to the exposure of water spinach to $\mathrm{Fe}_{3} \mathrm{O}_{4}$, free radicals production would induce stress to the plant and cause injury to the photosystem II that limits the active reaction center and light absorption in photosystem II. This parameter gives the same trend as the performance index as both shows the efficiency of photosynthesis process in the plant. Therefore, the application of $\mathrm{Fe}_{3} \mathrm{O}_{4}$ at higher concentration leads to plant stress and decrease the density of active reaction centers per photosystem II antenna chlorophyll.

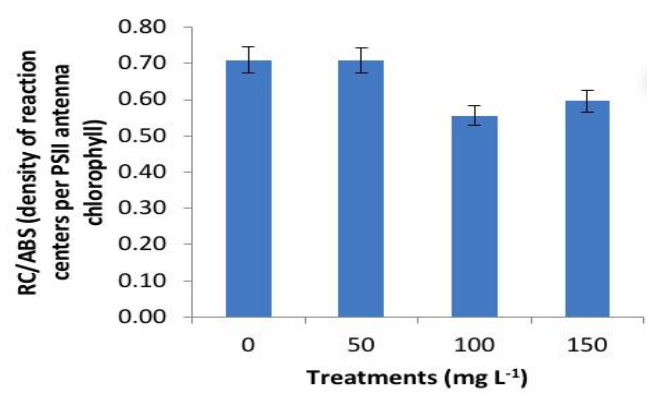

Fig. 14. The impact of magnetic nanoparticles on RCIABS (density of reaction centers per PSIl antenna chlorophyll) of Ipomoea aquatica

\subsection{Total Phenolics Content}

Based on Fig. 15, different concentration of $\mathrm{Fe}_{3} \mathrm{O}_{4}$ had influenced significantly on the phenolics content of water spinach $(P \leq 0.05)$. As the concentration of magnetic nanoparticles increases, the total phenolics content in the plant increased too. The lowest total phenolics content was observed in $0 \mathrm{mg} \mathrm{L}^{-1}$ iron oxide nanoparticles at $1.38 \mathrm{mg} \mathrm{GAE} / \mathrm{g}$ dry weight and the highest for $150 \mathrm{mg} \mathrm{L}^{-1}$ treatment at $2.29 \mathrm{mg}$ $\mathrm{GAE} / \mathrm{g}$ dry weight. The greater production of phenolics at higher concentration of magnetic 
nanoparticles may be a sign of the plant under stress. The production of secondary metabolites is an effort of the plant to defend itself from the further damage of plant cell and ensure the survival of plant. The higher production of phenolic stimulates antioxidant activity in the plant [44]. In order to the response of a plant towards environmental stresses and protecting itself from damages in plant cell, the production of phenolic compounds is essential to maintain the plant growth and reproduction [45]. Based on the study by previous researchers, phenolics compounds do contain antibiotic and antinutritional properties that help in the defense system of a plant. Phenolics compound usually stored in the epidermal cells of leaves and shoots besides central vacuole of guard cells. Phenolics content can be divided into two groups which are preformed phenolics and induced phenolics by which preformed phenolics are synthesized by the plant during development of plant tissues under normal condition. While, induced phenolics are produced when the plant faces physical injury, infection or environmental stresses due to heavy metal irradiation or temperature [14].

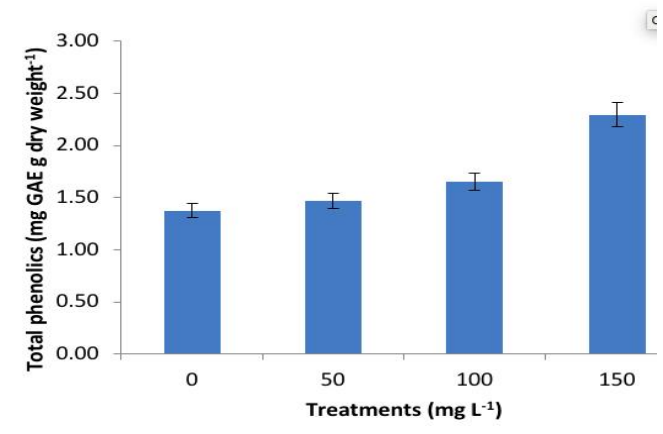

Fig. 15. The impact of magnetic nanoparticles on total phenolics content of Ipomoea aquatica

Data are mean \pm standard error of mean (SEM). $N=24$

\subsection{Total Flavonoids Content}

Based on Fig. 16, the production of total flavonoid content was significantly influenced by the application of magnetic nanoparticles at different concentrations of $\mathrm{Fe}_{3} \mathrm{O}_{4}(P \leq 0.05)$. At the end of experiment of $12^{\text {th }}$ week, the total flavonoid content in water spinach treated with $150 \mathrm{mg} \mathrm{L}^{-1} \mathrm{Fe}_{3} \mathrm{O}_{4}$ showed the highest reading at $1.70 \mathrm{mg}$ rutin/g dry weight followed by $100 \mathrm{mg} \mathrm{L}^{-}$ 1 treatment at $1.16 \mathrm{mg}$ rutin/g dry weight, $50 \mathrm{mg}$ $\mathrm{L}^{-1}$ treatment at $0.89 \mathrm{mg}$ rutin $/ \mathrm{g}$ dry weight and lastly $0 \mathrm{mg} \mathrm{L}^{-1}$ treatment at $0.38 \mathrm{mg}$ rutin $/ \mathrm{g}$ dry weight. From the result, it was observed that higher concentration of $\mathrm{Fe}_{3} \mathrm{O}_{4}$ increase the production of flavonoid in water spinach. The production of flavonoid is one of the determinants for the production of secondary metabolite in plant. It is oftenly observed that plant undergoing stress has higher total flavonoid content due to defensive mechanism in plant. Signaling in plant to produce secondary metabolites is usually stimulated by the accumulation of heavy metals like zinc, iron, and nickel which generates Reactive Oxygen Species (ROS) and induces oxidative stress in plant. Consequently, the induction of oxidative stress causes changes in signal transduction for the mechanism of gene coding and enzyme [13]. Besides, the production of ROS may cause damages to cell membrane, cell structure and photosynthetic site and thus the production of flavonoid at the generation site act as defensive mechanism due to its high antioxidant properties [14].

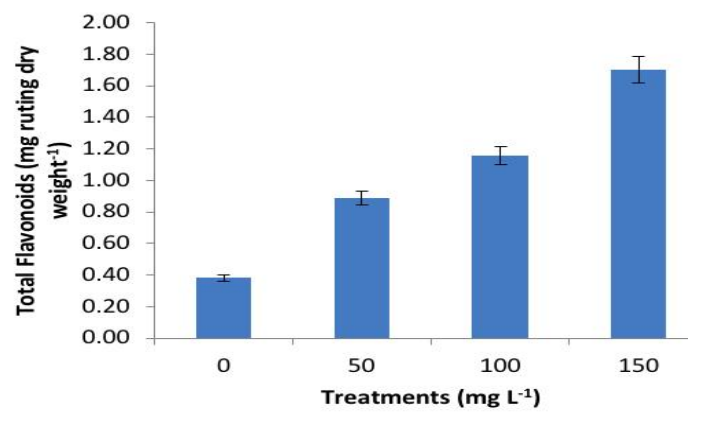

Fig. 16. The impact of magnetic nanoparticles on total flavonoids content of Ipomoea aquatica

Data are mean \pm standard error of mean (SEM). $N=24$

\section{CONCLUSION}

Overall, it was found that the application of magnetic nanoparticles which was in the form of iron oxide nanoparticles had influence on growth of Ipomoea aquatica. The plant height, plant temperature, total biomass and total chlorophyll content were significantly affected by the application of magnetic nanoparticles at higher concentration. Besides that, the leaf gas exchange characteristics were also influenced by the different concentrations of iron oxide nanoparticles. The net photosynthesis rate, transpiration rate, stomata conductance, maximum efficiency of photosystem II (Fv/fm), maximum quantum yield of phytochemical and 
non-photochemical process in photosystem II (Fv/fo), performance index and the density of reaction centers per PSII antenna chlorophyll of I. aquatica were significantly reduced at higher concentration of magnetic nanoparticles. While, water use efficiency and minimal fluorescence value of $I$. aquatica were increased with the increased of iron oxide nanoparticles concentration. In addition, the application of magnetic nanoparticles had significantly influenced the total flavonoids and total phenolics content in water spinach

\section{ACKNOWLEDGEMENT}

The authors would like to thank the Ministry of Higher Education Malaysia for The Fundamental Research Grant Scheme (FRGS) and the Research Management Centre, Universiti Putra Malaysia (UPM) for sponsoring this work.

\section{COMPETING INTERESTS}

Authors have declared that no competing interests exist.

\section{REFERENCES}

1. Salaries T. Department of Statistics Malaysia Press Release. 2016;1-4.

2. Department of Statistics Malaysia Press Release. Press Release Supply and Utilization Accounts Selected Agricultural Commodities, Malaysia 2012-2016. 2017;1-4.

3. Department of Statistics Malaysia Press Release. 2018;4-6.

Available:https://www.dosm.gov.my/v1/ind ex.php?r=column/pdfPrev\&id=TkpmM05E K3NBV0JRU1pmOUJnS3RCQT09

(Retrieved from on September 15, 2018)

4. Ibrahim $\mathrm{MH}$, Yasmin $\mathrm{N}$, Rahman $\mathrm{A}$, Amalina N, Zain M. Effect of nitrogen rates on growth and quality of water spinach (Ipomea aquatica). Annual Research \& Review in Biology. 2018;26(1):1-12.

DOI:https://doi.org/10.9734/ARRB/2018/40 352

5. Dua TK, Dewanjee S, Gangopadhyay M, Khanra R, Zia-Ul-Haq $M$, De Feo V. Ameliorative effect of water spinach, Ipomea aquatica (Convolvulaceae), against experimentally induced arsenic toxicity. Journal of Translational Medicine. 2015;13(1):1-17.

DOI:https://doi.org/10.1186/s12967-015-

0430-3
6. Xiao Q, Wong $\mathrm{MH}$, Huang L, Ye Z. Effects of cultivars and water management on cadmium accumulation in water spinach (Ipomoea aquatic Forsk.). Plant and Soil. 2015;391(1-2):33-49.

DOI:https://doi.org/10.1007/s11104-01524095

7. Markides $\mathrm{H}$, Rotherham $\mathrm{M}$, El Haj AJ. Biocompatibility and toxicity of magnetic nanoparticles in regenerative medicine. Journal of Nanomaterials. 2012;13-15. DOI:https://doi.org/10.1155/2012/614094

8. Lu AH, Salabas EL, Schüth F. Magnetic nanoparticles: Synthesis, protection, functionalization, and application. Angewandte Chemie - International Edition. 2007;46(8):1222-1244.

DOI:https://doi.org/10.1002/anie.20060286 6

9. Nair R, Varghese SH, Nair BG, Maekawa T, Yoshida Y, Kumar DS. Nanoparticulate material delivery to plants. Plant Science. 2010;179(3):154-163.

DOI:https://doi.org/10.1016/j.plantsci.2010. 04.012

10. Da Silva LC, Oliva MA, Azevedo AA, De Araujo JM. Responses of resting a plant species to pollution from an iron pelletization factory. Water Air Soil Pollut. 2006;175:241-256.

11. Lin C, Fugetsu B, Su Y, Watari F. Studies on toxicity of multi walled carbon nanotubes on Arabidopsis T87 suspension cells. J. Hazard. Mat. 2009;170:578-583.

12. Tiwari DK, Dasgupta-Schubert N, Villasenor LM, Tripathi D, Villegas J. Interaction of carbon nanotubes with mineral nutrients for the promotion of growth of tomato seedlings. Nano Stud. 2013;7:87-96.

13. Zhao J, Davis LC, Verpoorte R. Elicitor signal transduction leading to production of plant secondary metabolites. Biotechnology Advances. 2005;23:283333.

DOI:https://doi.org/10.1016/j.biotechadv.20 05.01 .003

14. Izad Al, Ibrahim $\mathrm{MH}$, Azurahanim $\mathrm{C}$, Abdullah C, Amalina N, Zain M. Growth, leaf gas exchange and secondary metabolites of Orthosiphon stamineus as affected by multiwall carbon nanotubes application. Annual Research \& Review in Biology. 2018;23:1-13.

DOI:https://doi.org/10.9734/ARRB/2018/38 113 
15. Karlsson HL, Cronholm P, Gustafsson J, Möller L. Copper oxide nanoparticles are highly toxic: A comparison between metal oxide nanoparticles and carbon nanotubes. Chem Res Toxicol. 2008;21(9):1726-32.

16. Martínez-Fernández D, Barroso D, Komárek M. Root water transport of Helianthus annuus L. under iron oxide nanoparticle exposure. Environmental Science and Pollution Research. 2016;23(2):1732-1741.

17. Liu R, Zhang H, Lal R. Effects of stabilized nanoparticles of copper, zinc, manganese, and iron oxides in low concentrations on lettuce (Lactuca sativa) seed germination: Nanotoxicants or nanonutrients? Water, Air, \& Soil Pollution. 2016;227(1):42.

18. Ruttkay-Nedecky B, Krystofova O, Nejdl L, Adam V. Nanoparticles based on essential metals and their phytotoxicity. Journal of Nanobiotechnology. 2017;15(1):119. DOI:https://doi.org/10.1186/s12951-0170268-3

19. Singh S, Singh BK, Yadav SM, Gupta AK. Applications of nanotechnology in agricultural and their role in disease management. Research Journal of Nanoscience and Nanotechnology. 2015;5(1):1-5.

20. Mahdavi M, Ahmad MB, Haron MJ, Namvar F, Nadi B, Rahman MZA, Amin J. Synthesis, surface modification and characterisation of biocompatible magnetic iron oxide nanoparticles for biomedical applications. Molecules. 2013;18(7):75337548.

21. Ibrahim $\mathrm{MH}$, Jaafar $\mathrm{HZ}$, Rahmat $\mathrm{A}$, Rahman ZA. The relationship between phenolics and flavonoids production with total non structural carbohydrate and photosynthetic rate in Labisia pumila Benth. under high $\mathrm{CO} 2$ and nitrogen fertilization. Molecules. 2011;16(1):162174.

22. Becker M, Asch F. Iron toxicity in rice conditions and management concepts. Journal of Plant Nutrition Soil Science. 2005;168:558-573.

DOI:https://doi.org/10.1002/jpln.200520504

23. Rui M, Ma C, Hao Y, Guo J, Rui Y, Tang $X$, Zhu S. Iron oxide nanoparticles as a potential iron fertilizer for peanut (Arachis hypogaea). Frontiers in Plant Science. 2016;7(6):1-10.

DOI:https://doi.org/10.3389/fpls.2016.0081 5
24. Dhoke SK, Mahajan P, Kamble R, Khanna A. Effect of nanoparticles suspension on the growth of mung (Vigna radiata) seedlings by foliar spray method. Nanotechnology Development. 2013;3(1). DOI: https://doi.org/10.4081/nd.2013.el

25. Chrispeels MJ, Agre P. Aquaporins: Water channel proteins of plant and animal cells. Elsevier Science. 1994;8073-8077.

26. Pressure T, Kirkham MB, Gardner WR, Gerloff GC. Regulation of cell division and cell enlargement. Plant Physiology. 1972;49:961-962.

27. Sheykhbaglou $R$, Sedghi M. Effects of nano-iron oxide particles on agronomic traits of soybean. Not Sci Biol. 2010;2(2): 112-113.

28. Jeyasubramanian K, Gopalakrishnan Thoppey UU, Hikku GS, Selvakumar N, Subramania A, Krishnamoorthy K. Enhancement in growth rate and productivity of spinach grown in hydroponics with iron oxide nanoparticles. RSC Advances. 2016;6(19):15451-15459. DOI: https://doi.org/10.1039/C5RA23425E

29. Du W, Tan W, Peralta-videa JR, Gardeatorresdey JL. University of California Center for Environmental Implications of Nanotechnology (UC). Plant Physiology and Biochemistry; 2016.

DOI:https://doi.org/10.1016/j.plaphy.2016.0 4.024

30. Gates DM. Transpiration and leaf temperature. Plant Physiology. 1968;19: 211-238.

31. Racuciu M, Creanga D, Olteanu Z. Water based magnetic fluid impact on young plants growing. Rom. Rep. Phys. 2009;61(2):259-268.

32. Britt DW, Johnson WP, Boyanov MI, Anderson AJ. $\mathrm{CuO}$ and $\mathrm{ZnO}$ nanoparticles: Phytotoxicity, metal speciation, and induction of oxidative stress in sandgrown wheat. Journal of Nanoparticle Research. 2012;14:1125.

DOI:https://doi.org/10.1007/s11051-0121125-9

33. Li J, Chang PR, Huang J, Wang Y, Yuan $H$, Ren $H$. Physiological effects of magnetic iron oxide nanoparticles towards watermelon. Journal of Nanoscience and Nanotechnology. 2013;13(8):5561-5567. DOI: https://doi.org/10.1166/jnn.2013.7533

34. Shweta, Tripathi DK, Shweta S, Swati S, Dubey NK, Chauhan DK. Impact of nanoparticles on photosynthesis: 
Challenges and opportunities. American Scientific Publishers. 2016;5(5):404-411. DOI:https://doi.org/10.1166/mat.2016.1327

35. Rizwan M, Ali S, Farooq M, Sik Y, Adrees M, Ibrahim M, Abbas F. Effect of metal and metal oxide nanoparticles on growth and physiology of globally important food crops: A critical review. Journal of Hazardous Materials. 2017;322(2):16. DOI:https://doi.org/10.1016/j.jhazmat.2016. 05.061

36. Blum A. Field crops research effective use of water (EUW) and not water-use efficiency (WUE) is the target of crop yield improvement under drought stress. Field Crop Research. 2009;112:119_ 123.

DOI:https://doi.org/10.1016/j.fcr.2009.03.0 09

37. Nurfarahin S. Growth, leaf gas exchange and secondary metabolites of water spinach (Ipomoea aquatica) as affected by carbon nanotubes application. Universiti Putra Malaysia, Malaysia; 2017.

38. Maxwell K, Johnson GN. Chlorophyll fluorescence -a practical guide. Journal of Experimental Botany. 2000;51(345):659668.

39. Gao J, Xu G, Qian H, Liu P, Zhao P, Hu Y. Effects of nano-TiO2 on photosynthetic characteristics of Ulmus elongata seedlings. Environmental Pollution. 2013;176:63-70.
40. Qi M, Liu Y, Li T. Nano-TiO 2 Improve the photosynthesis of tomato leaves under mild heat stress. Biology Trace Element Research. 2013;156:323-328. DOI:https://doi.org/10.1007/s12011-0139833-2

41. Mehta P, Jajoo A, Mathur S, Bharti S. Plant physiology and biochemistry chlorophyll a fluorescence study revealing effects of high salt stress on photosystem II in wheat leaves. Plant Physiology et Biochemistry. 2010;48(1):16-20.

DOI:https://doi.org/10.1016/j.plaphy.2009.1 0.006

42. Živčák $M$, Brestič $M$, Olšovská $K$, Slamka $P$. Performance index as a sensitive indicator of water stress in Triticum aestivum L. Plant Soil Environment. 2008;54(4):133-139.

43. Appenroth K, Sto J. Multiple effects of chromate on the photosynthetic apparatus of Spirodela polyrhiza as probed by OJIP chlorophyll a fluorescence measurements. Environmental Pollution. 2001;115:49-64.

44. Kim D, Weon S, Lee CY. Antioxidant capacity of phenolic phytochemicals from various cultivars of plums. Food Chemistry. 2003;81:321-326.

45. Subbiah R, Veerapandian M, Yun KS. Nanoparticles: Functionalization and multifunctional applications in biomedical sciences. Curr. Med. Chem. 2010;17: 4559-4577.

(c) 2019 Yusufirashim et al.; This is an Open Access article distributed under the terms of the Creative Commons Attribution License (http://creativecommons.org/licenses/by/4.0), which permits unrestricted use, distribution, and reproduction in any medium, provided the original work is properly cited.

Peer-review history:

The peer review history for this paper can be accessed here: http://www. sdiarticle3.com/review-history/47894 